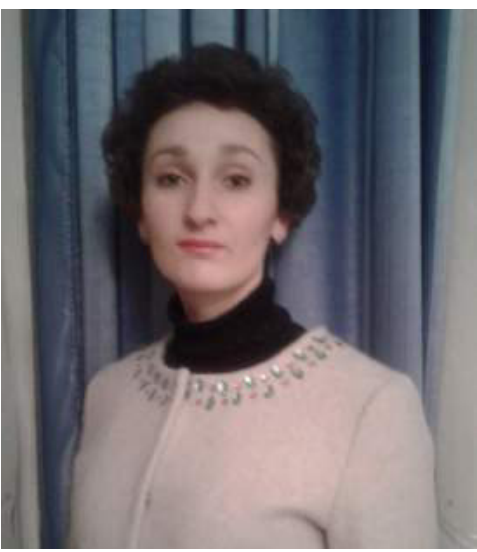

Ірина Бей,

аспірант,

ДВНЗ «Прикарпатський національний університет імені Василя Стефаника»

(м. Івано-Франківськ)

Iryna Bey,

Postgraduate student, Vasyl Stefanyk Precarpathian National University (Ivano-Frankivsk) beyirene@gmail.com

\title{
ПІДГОТОВКА МАЙБУТНІХ УЧИТЕЛІВ ІНОЗЕМНОЇ МОВИ ДО ПРОЕКТНОЇ ДІЯЛЬНОСТІ У ЗАГАЛЬНООСВІТНІЙ ШКОЛІ ПЕРШОГО СТУПЕНЯ
}

\section{TRAINING FUTURE FOREIGN LANGUAGE TEACHERS FOR THE PROJECT ACTIVITY AT PRIMARY SCHOOL}

У статті розкрито теоретичні засади професійної підготовки майбутніх учителів іноземної мови до проектної діяльності учнів початкової школи, обгрунтовано сутність поняття «проектна діяльність молодших школярів»: охарактеризовано їі складові та шляхи використання в загальноосвітній школі першого ступеня. Визначено дидактичні принципи підготовки студентів до впровадження методу проектів, виділено показники готовності майбутніх фахівців до інноваційної діяльності учнів початкових класів. у статті зазначається, що ця готовність складається з таких компонентів, як мотиваційний (інтерес до окресленої діяльності); теоретичний (знання ії основних характеристик, методів, вимог щодо ефективного впровадження); рефлексивний (аналіз очікуваних результатів).

Ключові слова: проектна діяльність, метод проектів, майбутні учителі іноземної мови, молодші школярі, професійна підготовка, готовність до професійної діяльності.

The article deals with theoretical principles of vocational training of future foreign language teachers for the project activity of primary school pupils. It explains the nature of the concept «project activity of junior pupils", characterizes its components and ways of implementation at primary school. There have also been defined didactic principles of training students for employing the method of projects. Evidence of the readiness of future professionals for introducing innovative activities among junior pupils has been highlighted.

The article points out that this readiness comprises motivational (interest in the above mentioned activity); theoretical (knowledge of its main characteristics, methods, requirements for effective implementation); reflexive (analysis of the expected results) components.

Keywords: project activity, method of projects, future foreign language teachers, junior pupils, vocational training, readiness for professional activity.

В статье раскрыты теоретические основы профессиональной подготовки будущих учителей иностранного языка к проектной деятельности учащихся начальной школы, обоснованно сущность понятия «проектная деятельность младших школьников»; охарактеризованы ее составляющие и пути использования в общеобразовательной школе первой ступени. Определены дидактические принципы подготовки студентов к внедрению метода проектов, выделены показатели готовности будущих специалистов к инновационной деятельности учащихся начальных классов. В статье отмечается, что эта готовность состоит из таких компонентов, как мотивационный (интерес к обозначенной деятельности); теоретический (знания ее основных характеристик, методов, требований по эффективному внедрению); рефлексивный (анализ ожидаемых результатов).

Ключевые слова: проектная деятельность, метод проектов, будущие учителя иностранного языка, младшие школьники, профессиональная подготовка, готовность к профессиональной деятельности.

Постановка проблеми в загальному вигляді та її зв'язок з важливими науковими та практичними завданнями. У період інноваційних змін у галузі освіти особливо актуальною постає проблема формування готовності майбутніх учителів до проектної діяльності у загальноосвітніх навчальних закладах. Вона зумовлена важливістю змін у соціокультурному просторі суспільства на шляху до ринкової системи, соціальним замовленням на підготовку конкурентоспроможного педагога, здатного успішно вирішувати завдання модернізації освітньої галузі, примножувати національно-культурний та економічний потенціал держави.

Актуальність теми дослідження зумовлена сучасними тенденціями в освіті, адже сьогодні вищий навчальний заклад повинен забезпечити формування і розвиток інтелектуальної, творчої та ініціативної особистості, здатної 
жити в принципово нових умовах, реалізувати себе в житті, бути успішною і сприяти розвитку суспільства. Ось чому великого значення набуває впровадження в навчальний процес методу проектів, який, за твердженням вчених, являє собою педагогічну систему, що має певну сукупність взаємопов'язаних засобів і процесів, необхідних для створення організованого та цілеспрямованого педагогічного впливу на формування особистості майбутнього вчителя.

Аналіз останніх досліджень і публікацій, у яких започатковано розв'язання проблеми. Обґрунтовуванню теоретичних засад формування готовності педагога до різних видів професійної діяльності присвячено наукові розвідки І. Гавриш, К. Дурай-Новакової, Н. Кузьміної, А. Ліненко, К. Макагон, Л. Мітіної, О. Пєхоти, В. Сластьоніна та ін. Учені розкрили зміст, структуру й рівні готовності педагогів до інноваційної діяльності.

Дослідження складової інноватики - проектної діяльності - здійснювали І. Буравська, Л. Ващенко, В. Вербицький, С. Гончаренко, Т. Довбенко, В. Докучаєва, Е. Полат, С. Шевцова та ін. Ними було визначено напрями цієї діяльності, види навчальних проектів, принципи їх впровадження в навчальний процес вищих навчальних закладів.

Однак, дослідження проблеми на теоретичному рівні показало, що у фаховій педагогічній літературі поняття «навчальний проект» тлумачиться неоднозначно: як «дидактичний засіб активізації пізнавальної діяльності, розвитку креативності та водночас формування певних особистісних якостей» (С. Шевцова); як «форма організації занять, яка передбачає комплексний характер діяльності всіх її учасників з метою отримання освітньої продукції за певний проміжок часу - від одного уроку до кількох місяців» (Е. Полат); як «обґрунтована й усвідомлена діяльність, спрямована на формування певної системи інтелектуальних і практичних умінь» (С. Гончаренко); як «самостійно розроблений і виготовлений продукт (матеріальний чи інтелектуальний) від ідеї ї̈ втілення, виконаний під контролем і з консультаціями викладача» (І. Буравська) та ін.

Поняття «метод проектів» також визначається науковцями по-різному: і як конкретна практика роботи педагога, спрямована на формування у студентів певної системи інтелектуальних і практичних умінь; і як комплексний метод навчання; і як педагогічна технологія; і як система навчання.

Вітчизняними та зарубіжними вченими зроблено вагомий внесок у досліджувану проблему, але більшість їхніх робіт пов'язана з розглядом окремих питань проектної діяльності.

Отже, важливі аспекти формування проектної компетентності майбутніх учителів іноземної мови, створення цілісної системи організаційно-методичного забезпечення педагогічного проектування в загальноосвітньому навчальному закладі ще залишаються недослідженими та потребують подальшого розв'язання.

Формування мети статті. Мета статті - на основі теоретичного дослідження проблеми визначити наукові засади підготовки майбутніх учителів іноземної мови до проектної діяльності у загальноосвітній школі першого ступеня.

Виклад основного матеріалу дослідження з повним обґрунтуванням отриманих наукових результатів. В останні роки дедалі більшої актуальності в освітньому процесі набуває проблема використання в навчанні прийомів і методів, які сприяють формуванню вміння самостійно здобувати нові знання, збирати необхідну інформацію, висувати гіпотези, робити висновки.

Провідна роль в цьому процесі, на думку вчених і практиків, належить проектній діяльності, основною метою якої $€$ «створення з боку педагога таких умов під час освітнього процесу, за яких його результатом $€$ індивідуальний досвід проектної діяльності учня, оскільки таке навчання розвивається у продуктивній діяльності, воно розширює сферу суб'єктивності в процесі самовизначення, творчості та конкретної участі учня» [4, с.168].

Як відомо, проектна діяльність молодших школярів передбачає самостійне вирішення певних проблем 3 отриманням конкретних результатів задля формування в учнів глибоких предметних знань, умінь планувати свою творчу роботу, аналізувати, порівнювати, систематизувати, класифікувати, узагальнювати отриману інформацію, оформлювати та презентувати її іншим (наприклад, в класі або у позакласній діяльності).

Аналізуючи концептуальні положення навчального проектування, В. Химинець зазначає, що «воно орієнтоване насамперед, на самостійну діяльність учнів - індивідуальну, парну або групову, яку учні виконують протягом визначеного періоду, причому під час використання технології вирішують низку різнорівневих дидактичних, виховних і розвивальних завдань» [4, с.169]. Отже, таким чином розвиваються пізнавальні навички учнів, у них формується вміння самостійно конструювати знання, орієнтуватися в інформаційному просторі, активно розвивається критичне мислення, сфера комунікації тощо. Основним методом цієї діяльності виступає «метод навчальних проектів», який, за твердженням вчених, - можливий засіб розв'язання актуальних проблем, адже учні часто не вміють перетворювати інформацію в знання, здійснювати цілеспрямований пошук інформації, а велика кількість інформації часто не призводить до системності знань.

Відсутність у школярів інтересу, мотиву до особистісного зростання, до самостійного здобуття нових знань результат провідного типу діяльності учнів - репродуктивного, який спрямований на відтворення знань, відірваних від життя.

Саме тому основи проектної діяльності учня мають закладатися саме в початковій школі, в процесі навчання поступово розвиватися і поглиблюватися в міру дорослішання і усвідомлення учнем своїх професійних, соціальних і громадянських потреб і обов'язків. Вихідними для цієї діяльності у молодших школярів мають бути проектні 
завдання, адже саме проектне навчання створює унікальні передумови для розвитку ключових компетентностей учнів, самостійності в освоєнні нового, стимулюючи їхню природну допитливість і творчий потенціал.

Отже, вважаємо, що «проектна діяльність - це та якісна основа, яка може реалізувати гуманістичний підхід до навчання, оскільки сприяє формуванню творчої особистості, діяльність якої спрямована на впровадження власних ідей, перетворення навколишнього середовища, виходячи з різних потреб на основі своїх можливостей» [1, с.6].

Аналіз теоретичних засад проектної діяльності учнів показав, що вона пов'язана, перш за все, з пошуковою діяльністю: вирішенням учнями творчих, дослідницьких завдань із заздалегідь невідомим рішенням і передбачає наявність основних етапів, характерних для дослідження в науковій сфері - постановку проблеми (або виділення основоположного питання), вивчення теорії, пов'язаної з обраною темою, висунення гіпотези дослідження, підбір методик і практичне оволодіння ними, збір власного матеріалу, його аналіз і узагальнення, самостійні висновки, представлення (презентація) виконаної роботи.

О. Савченко стверджує, що формування досвіду пошукової діяльності учнів в атмосфері загального захоплення цікавою справою не лише має розвивальне значення, а й об'єднує процеси навчання і виховання, стимулює пізнавальні потреби. Протягом початкового навчання вчителі мають залучати молодших школярів до виконання самостійних завдань різної складності, до систематичного розв'язування пізнавальних завдань за допомогою прийомів розумової діяльності, участі в евристичних бесідах проведення елементарних досліджень [3]. Відповідно, продуктом дослідницької діяльності школяра $є$ не тільки знання, які він здобуває, а й способи пізнавальної діяльності, які впливають на інтелектуальний розвиток особистості.

Важливість проектної діяльності, за твердженням В. Химинця, полягає в тому, що «учень або група учнів розв'язують ту чи іншу проблему, яка з одного боку, стимулює використання різноманітних методів, засобів навчання, а з іншого - інтегрування знань, умінь із різних галузей науки, техніки, творчості» [4, с.169]. Iї результативність залежить від раціонального застосування умов впровадження проектної діяльності в навчальний процес.

Серед найбільш поширених вважаються: вироблення уявлень про кінцевий продукт, розроблення етапів проектування (вироблення концепції, визначення цілей і завдань проекту, доступних і оптимальних ресурсів діяльності, створення плану, програм і організація діяльності з реалізації проекту) та реалізацію проекту, включаючи його осмислення і рефлексію результатів діяльності. Причому сам проект виступає формою організації такої навчальної діяльності і являє собою спосіб досягнення дидактичної мети через детальне розроблення проблеми. Він повинен завершитися відчутним практичним результатом, наприклад, виставою, святом, картиною, кресленням тощо.

Отже, метод проектів - це спосіб досягнення дидактичної мети через детальне розроблення значущої для учнів проблеми, розв'язання якої повинне відбуватися на основі зацікавленості учня і завершуватися цілком реальним, відчутним практичним результатом, оформленим відповідним чином.

Переконані, що багато в чому розвиток у молодшого школяра інтересу до застосування цього методу залежить від загальної атмосфери в класі. Учень має сприймати клас як свій колектив, де є справедливість, доброзичливість, вимогливість. При цьому вимоги вчителя дитина має сприймати як систематично діючі правила колективу, виконання яких необхідне для її нормальної життєдіяльності. Очевидно, що при організації дослідницької діяльності молодшого школяра в навчальному процесі ідеальною є ситуація, коли створюється атмосфера творчого пошуку, а сам процес роботи приносить задоволення, що спонукає до подальших дій.

Вчитель в цьому випадку виступає не як керівник, а як людина, яка створює сприятливі умови для самостійного й осмисленого навчання, активізує та стимулює допитливість і пізнавальні мотиви учнів, організовує групову навчальну роботу, підтримує прояви оперативних тенденцій, надає учням різносторонній навчальний матеріал.

Тому організація пошуково-дослідницької діяльності молодших школярів передбачає наявність високого ступеня методичної підготовленості учителя та виявлення напрямів її вдосконалення. Крім цього, необхідно акцентувати увагу на меті, змісті, формі, методах і засобах організації, що передбачає проектування програми включення молодших школярів у пошуково-дослідницьку (проектну) діяльність, її поетапну реалізацію з систематичним аналізом одержуваних даних і коригування відповідно до аналізу результатів.

Дослідження теоретичних засад підготовки студентів до проектної діяльності учнів показало, що майбутньому вчителю іноземної мови потрібно в повній мірі усвідомити значення проектної діяльності в початковій школі, знати її особливості та принципи організації. Аналіз наукових джерел дозволив нам визначити основні принципи цієї підготовки, серед яких виділяємо: «принцип активності (цілеспрямоване активне сприймання проблеми проекту, її переосмислення та вирішення); принцип продуктивності (прагматична спрямованість діяльності на отримання соціально ціннісного результату); принцип технологічності (виконання взаємообумовлених навчальних дій у чітко визначеній послідовності); принцип саморозвитку (створення розвивального середовища, в якому в результаті реалізації поставленої мети будуть впроваджені нові проекти)» [1, с.7].

Визначення дидактичних принципів підготовки майбутніх учителів іноземної мови до організації інноваційної проектної діяльності дозволяє викладачу вищого навчального закладу планувати систему засобів формування готовності студентів до професійної діяльності. Ця готовність має, перш за все, відображати інтерес до окресленої діяльності (мотиваційний компонент готовності), знання їі основних характеристик, методів, вимог щодо її ефективного впровадження (теоретичний компонент); умінь визначати їі тематику, програму, кількість 
учасників та їхні обов'язки, чітко формулювати учням мету, завдання, розробляти інструкції з оформлення очікуваного матеріального результату та аналізувати результат (рефлексивний компонент).

Як зазначає І. Дичківська, «готовність майбутніх учителів до інноваційної діяльності за своєю структурою та спрямуванням визначається такими показниками, як: усвідомлення потреби запровадження педагогічних інновацій у власній педагогічній практиці; інформованість про новітні педагогічні технології, знання новаторських методів роботи; зорієнтованість на створення власних творчих завдань і методик, налаштованість на експериментальну діяльність; готовність до подолання труднощів, пов'язаних зі змістом та організацією інноваційної діяльності; володіння практичними навичками освоєння педагогічних інновацій та розроблення нових» [2, с.281].

Отже, готовність педагога до інноваційної діяльності $€$ показником його здатності нетрадиційно вирішувати актуальні для особистісно-орієнтованої освіти проблеми. у зв'язку з цим до керівника проекту висуваються особливі вимоги, адже основною метою вчителя має бути не передача знань, а організація пошукової діяльності учнів. Вчитель сам повинен володіти методами досліджень, вміти висувати гіпотези, шукати розв'язання проблем; він повинен бути зацікавленим в інтелектуальній діяльності учнів, мати високу культуру мислення, бути дидактично та методично обізнаним. Таким чином змінюється і роль педагога: він вже не є формальним носієм знань та функцій, а стає консультантом та порадником.

Висновки і перспективи подальших досліджень. На основі аналізу наукових джерел встановлено, що педагогічне проектування $€$ базовою категорією науково-педагогічного знання. Воно характеризується міждисциплінарністю, комплексністю, системністю; має інтегрований, прогностичний та інноваційний характер; передбачає створення таких умов під час освітнього процесу, за яких моделюється розвиток здатності кожного учня визначати і реалізовувати спільну мету роботи та знаходити шляхи її досягнення.

Під проектною компетентністю майбутнього вчителя іноземної мови розуміємо сукупність знань, умінь, мотивів і особистісних якостей, необхідних для організації проектної діяльності учнів загальноосвітньої школи першого ступеня.

Дослідження проблеми на теоретичному рівні дозволило виокремити шляхи організаційно-методичного забезпечення педагогічного проектування в початковій школі, які представлені трьома взаємопов'язаними складовими - концептуальним, що включає мету, завдання, принципи та наукові підходи; змістовим, який містить відповідні організаційні, педагогічні і методичні умови та технологічно-процесуальним, що передбачає діагностичне, технологічне та рефлексивне забезпечення навчального процесу.

1. Бей І. Наукові засади проектних технологій як компоненту системи професійної підготовки майбутнього вчителя / І. Бей // Збірник матеріалів III Міжнар. наук.-практ. конф. «Особистість, суспільство, політика». - Ч.2. - Люблін: WSEI, 2015. - С. 6-8.

2. Дичківська І. Інноваційні педагогічні технології: Навч. посіб./ І. Дичківська. - К.: Академвидав, 2004. - 351 с.

3. Савченко О. Дидактика початкової освіти : підручник для студентів вищих навчальних закладів / О. Савченко. - К. : Грамота, 2012. - 504 с.

4. Химинець В., Кірик М. Інновації в початковій школі / В. Химинець, М.Кірик. - Тернопіль: Мандрівець, 2009. - 312 с.

\section{Reference}

1. Bey I. Naukovi zasady proektnykh tekhnologiy yak komponentu systemy profesiynoyi pidhotovky maybutn'oho vchytelya / I. Bey// Zbirnyk materialiv III Mizhnar. nauk.-prakt. konf. «Osobystist', suspil'stvo, polityka». - Ch.2. - Lyublin: WSEl, 2015. - S. 6-8.

2. Dychkivska I. Innovatsiyni pedagogichni tekhnologiyi: Navch. posib. / I. Dychkivska. - K.: Akademvydav, $2004 .-351$ s.

3. Savchenko O. Dydaktyka pochatkovoyi osvity : pidruchnyk dlya studentiv vyshcykh navchal'nykh zakladiv / O. Savchenko. - K. : Hramota, 2012. - $504 \mathrm{~s}$.

4. Khymynets' V., Kiryk M. Innovatsiyi v pochatkoviy shkoli / V. Khymynets', M. Kiryk. - Ternopil': Mandrivets', 2009. - 312 s.

Рецензент: Лисенко Н.В., доктор педагогічних наук, професор, ДВНЗ «Прикарпатський національний університет імені Василя Стефаника»*

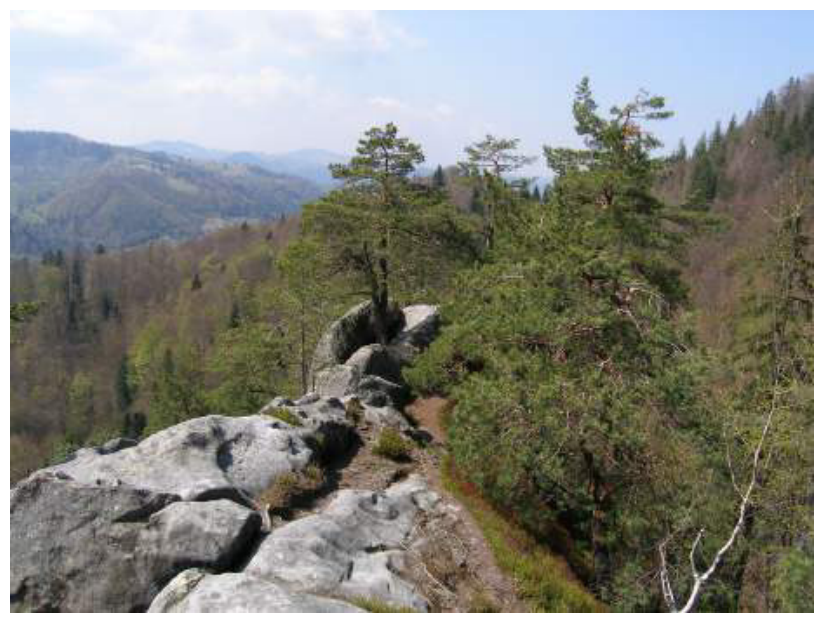

